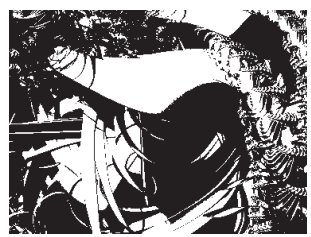

\title{
RURAL AREA TRANSFORMATION: FROM CROPLAND TO MINE FIELDS - ZEMUNIK DONJI MUNICIPALITY (CROATIA) CASE STUDY
}

Želika ŠILJKOVIĆ, Anica ČUKA, Ana PEJDO University of Zadar, Zadar

UDK: 316.334.55(497.5Zemunik Donji)

Izvorni znanstveni rad

Primljeno: 8. 4. 2010.

This paper analyses socio-economic and land use changes in the Zemunik Donji Municipality of the Republic of Croatia during the 19th and 20th centuries. It also provides an overview of the current suspected landmine areas and civilian casualties in this region and the influence of landmines on population numbers. The Zemunik Donji Municipality is an integral part of Ravni kotari, one of the most important agricultural regions in Coastal Croatia. Throughout history, people living in this region were mostly engaged in agriculture (both cropping and pastoral activities), through which they achieved prosperity. In spite of extensive processes of depopulation and abandonment of cultivated land during the second half of the 20th century in this and other parts of Coastal Croatia, the landscape of the Zemunik area has retained the characteristics of an agricultural region. As a result of the recent Croatian War of Independence, considerable change has occurred within the Municipality with abandonment of agricultural land, and fertile fields becoming landmine fields to pose a major obstacle to economic activity.

Keywords: Zemunik Donji Municipality, land use, landmine fields 
In many developing countries where agriculture is a major source of income, the presence of landmine contaminated agricultural land represents a major obstacle in both social and economic revival efforts. It has become clear that solving the problem of landmine contamination is not only a humanitarian imperative, but is also essential for economically efficient, socially fair and environmentally sustainable development (GICHD, 2004). It is evident that the largest corpus of scientific research dealing with landmines is focused on developing world countries (Day, 1998; Andersson et al., 2003; Harpviken et al., 2003; Harpviken \& Skåra, 2003; Horwood, 2003; Kjellman et al., 2003). On the other hand, many regions, particularly transitional countries, which were recently affected by the war and which deal with the same problem, are rarely mentioned in such context.

As many as a hundred and one countries and ten areas in the world are affected by landmine contamination (ICBL, 2008). There is no exact data on the number and position of all landmines in the world, although it is estimated that there are currently more than 100 million landmines worldwide (Mahmudi-Azer, 2006; Berhe, 2007; ICBL, 2008). Despite the fact that landmines represent one of the most hazardous soil contaminants (ICBL, 2006), they are one of the least investigated problems both from an environmental and socio-economic point of view. Berhe (2007) provides an overview of the environmental impact of landmines regarding land degradation, sustainable development and social, political and economic dimensions of the ecological crisis caused by landmines. Lately, the interests of geographers and demographers have converged and they have become more oriented on dealing with populations living in hazardous situations. Their studies are more focused on the research of natural phenomena and their influence on population (Marandola \& Hogan, 2006), than on environmental risks caused by social and political changes, such as the landmine issue. The socio-economic impact of landmines has been studied in works by Harris $(2000,2002)$, Elliot \& Harris (2001) and Gibson et al. (2007). Taking into account the economics of landmine clearance, Harris (2000) and Elliot \& Harris (2001) have dealt with issues in Cambodia, Afghanistan and Mozambique, while Gibson et al. (2007) have provided a thorough analysis of the value of statistical life (VSL), and the economics of landmine clearance in developing countries. Among others, the main benefits of demining include increased agricultural output, decreased transport time and running costs, reduced human casualties and saved costs of supporting refugees and displaced persons (Harris, 2002; Mitchell, 2004).

During the 20th century, Croatia, as a transitional country, went through the processes of depopulation, abandonment 
DRUŠ. ISTRAŽ. ZAGREB GOD. 20 (2011), BR. 4 (114)

STR. 1163-118

ŠILJKOVIĆ, ž. ČUKA, A., PEJDO, A. RURAL AREA... of agriculture (especially of cattle breeding) and the regeneration of autochthonous vegetation, similarly as some other rural parts of the Mediterranean, especially those in the regions oriented towards tourism or those with limiting environmental factors (Ruiz Perez, 1990; Lasanta-Martínez et al., 2005; Roura-Pascual et al., 2005; Kizos \& Koulouri, 2006; Petanidou et al., 2008; Zomeni et al., 2008). Additional impetus for enforced land use changes was the Croatian War of Independence (1991-1995) which resulted both in landmine contamination and population changes. Population, as an important factor influencing environment changes has been in the focus of interest of many researchers (Pebley, 1998; Goldewijk \& Ramankutty, 2004; Gilland, 2006; Harte, 2007; Potts, 2007; Rain et al., 2007), with changes in the number of inhabitants and demographic structures being some of the driving forces of human-induced landscape change (Bürgi et al., 2004). The Zemunik area, located in the hinterland of the coastal urban centre Zadar, was chosen as a case study since it represents a typical rural region that experienced major transformation from an intensively agricultural to depopulated region with a significant share of landmine fields. The aim of the study was to show the effects of the most important socio-economic changes on the rural development of the Zemunik area, from the second half of the 19th century to the present time. Another goal was to prove that the presence of landmines is an important obstacle for demographic and economic development, especially in the rural area. It is also one of the crucial factors that influenced drastic changes in the visual identity of the traditional agricultural region.

\section{METHODOLOGY}

Authors have focused primarily on analyses of archival data regarding land use and social conditions in rural areas of the Municipality in the 19th century. Therefore, most of the attention in the study was paid to the socio-economic and land use changes which were the result of intensive processes of industrialization and migration to the coastal area. Data on mine suspected areas and civilian casualties in Croatia and in Zemunik Donji Municipality were retrieved from the Croatian Mine Action Centre (CROMAC).

Data on population numbers, ethnic and economic structures were retrieved from the Croatian Central Bureau of Statistics. Geographical descriptions, the demographic and economic situation in 1844 and land use data for 1857 were analyzed based on the Economic description of the cadastral municipality made as a part of the so-called Second cadastral and geodetic survey completed by the Austrian Monarchy (in Italian language) in the first half of the 19th century, from the State Archives in Split. Those data were compared with the Cen- 
DRUŠ. ISTRAŽ. ZAGREB GOD. 20 (2011),

BR. 4 (114),

STR. 1163-1181

ŠILJKOVIĆ, Ž.,

ČUKA, A., PEJDO, A.:

RURAL AREA...

\section{STUDY AREA}

(1) FIGURE 1

Mine suspected area

in Zemunik Donji

Municipality sus data from 1900 and present land use categorisation derived from the official cadastral records.

Significant inconsistencies, especially those regarding present categories of land use are confirmed by detailed analysis of 244 cadastral parcels marked as mine suspected. Based on maps retrieved from CROMAC, branch-office Zadar, and data on cadastral land categorization, the authors determined the pre war land use of currently mine suspected parcels.

The Zemunik area i.e. Zemunik Donji Municipality covers an area of $54.59 \mathrm{sq}$. $\mathrm{km}$ or $1.56 \%$ of the total area of Zadar County and it consists of three settlements: Zemunik Donji, Zemunik Gornji and Smoković, having 1,903 inhabitants in total (according to the 2001 Population Census). Out of 5,459 ha of arable land only 2,680 ha is cultivated. The overall quality of arable land in Zemunik Donji Municipality is very high and it is considered to be one of the most valuable agricultural regions within Zadar County (Institute for Physical Planning, 2006). At the moment, one of the main obstacles for agricultural use is the presence of landmines in several zones of the study area (Figure 1).

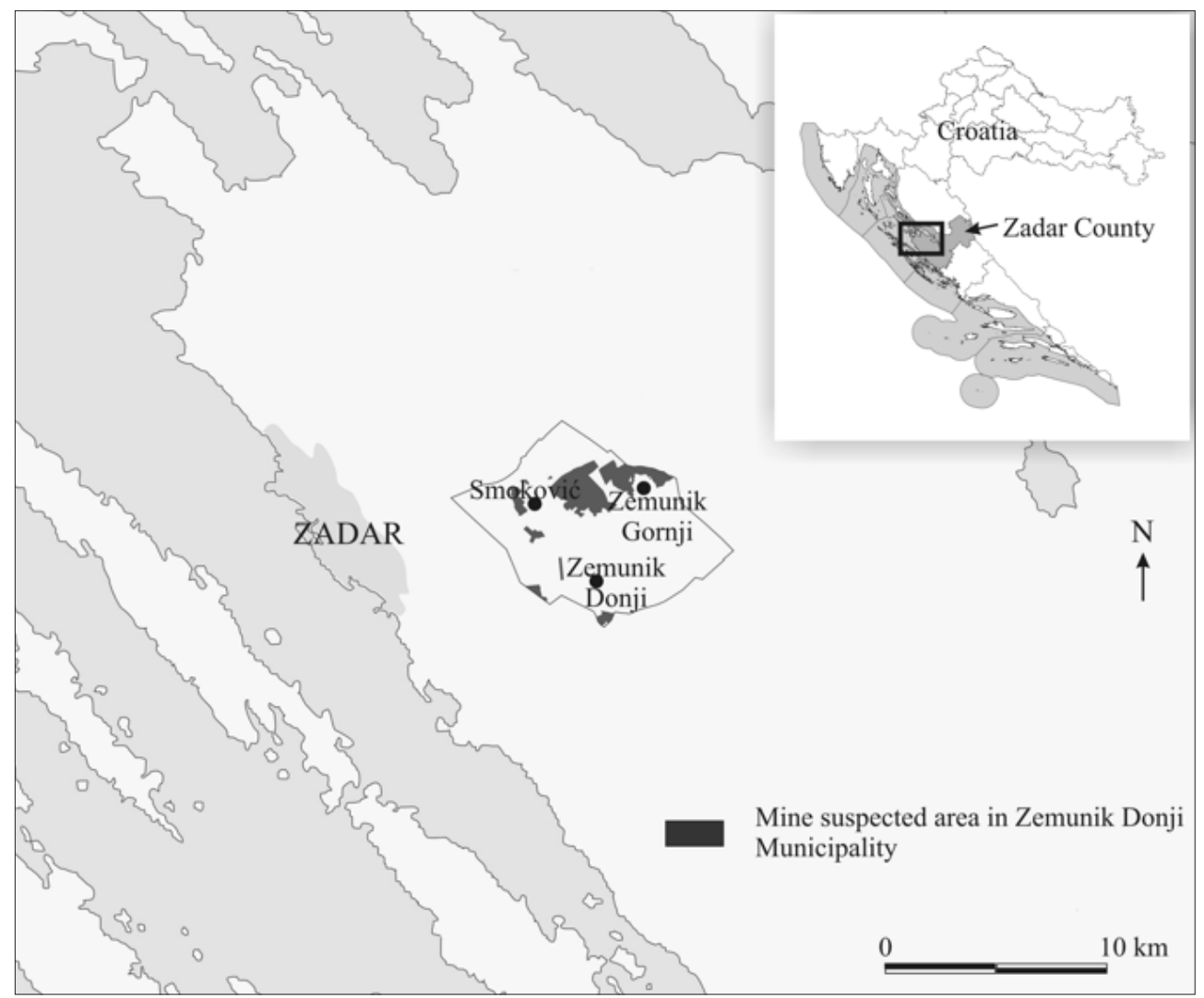


DRUŠ. ISTRAŽ. ZAGREB GOD. 20 (2011), BR. $4(114)$

STR. 1163-118

ŠILJKOVIĆ, ž. ČUKA, A., PEJDO, A. RURAL AREA...
The Republic of Croatia declared its independence in 1991, after the disintegration of the Socialist Federal Republic of Yugoslavia. In order to stop Croatia's drive for independence, Croatian Serbs started an armed rebellion. The Yugoslav Army that was supported by Slobodan Milosevic's regime in Serbia joined rebellions and it finally resulted in aggression on Croatia and the beginning of the Croatian War of Independence which lasted until 1995. Although the war ended 15 years ago, the country is still contaminated with landmines and explosive remnants. Mine suspected areas are located along the former frontline between Serbs and Croats. After the Croatian War of Independence, both parties should have surrendered the maps indicating the exact location of mines. Just as in other Croatian counties, the laying of mines by both sides, either in order to protect defensive positions, in areas of strategic importance, such as railway lines, roads, airports and power stations, and also in the vicinity of housing facilities, was largely unplanned. Without mapping or documentation, demining, already expensive and complicated, became an even more dangerous task (Radonić et al., 2004). On January 1st 2008 the total area suspected to be mine affected in the Republic of Croatia was $997 \mathrm{sq}$. km. Minefields and other areas suspected of mine contamination and unexploded ordnance were located in 12 out of 21 counties in Croatia. According to data provided by Croatian Mine Action Centre (CROMAC) the mine suspected area was reduced to $954.5 \mathrm{sq}$. $\mathrm{km}$ in 2009 (CROMAC, 2009a). According to the bulletin issued by CROMAC (2006), mine suspected areas needs meet the following specifications before being considered for treatment with a demining machine: the area should be flat or inclined up to $20 \%$, with few trees or grassy with sparse low bushes, well drained, and accessible to vehicles. The terrain within Zemunik Donji Municipality matches this description, thus providing ideal circumstances for successful demining. Furthermore, demining should be completed as soon as possible, not only to initiate economic prosperity, but also to capitalise on the current conducive terrain. If left for any length of time, vegetation will grow back and need to be either burned or cut down before beginning the demining process (Antonić et al., 2001).

Mine-affected states are legally required to clear all mined areas on their territory within 10 years of signing up to the Mine Ban Treaty. According to the preliminary plans made by the Croatian government, all landmines and UXO (unexploded ordnance) should have been removed by 2009, but during 2008 the Government declared that it would fail to meet the deadline (ICBL, 2008). Starting from 1991 until today landmines have been found and removed from $250 \mathrm{sq} . \mathrm{km}$ in the Republic of Croatia while the mine suspected area in the Zemunik Donji Municipality on 1st January 2008 was 6.12 sq. km. 


\section{DEMOGRAPHIC TRENDS}

Demographic dynamics and economic changes directly influence the economic development, thereby the change in the land use patterns (Bürgi et al., 2004). During the second half of the 20th century in most of the rural settlements in the Zadar hinterland there was an evident decline in the overall population number, whereas that was not the case in the Zemunik area. The population of Zemunik Donji Municipality did not decline until as late as 1971 as a result of inhabitants emigrating to urban settlements along the Adriatic coast, i.e. Zadar and Split, or to the country's capital, Zagreb. The most significant decline in population number was the result of the Croatian War of Independence and it was registered in the last population census in 2001. When compared with data from 1991, the total population decreased by 59.1\%. All three settlements suffered direct war damage on housing facilities and infrastructure. The consequences of the War can still be seen even today. Without the complete infrastructural reconstruction the prospect for future economic growth will remain limited.

(1) TABLE 1

Population trends in Zemunik Donii

Municipality from 1857 to 2001
In 2001, only 50 inhabitants lived in Smoković, while according to the 1991 population census there were 1,029 inhabitants. An almost identical situation was recorded in Zemunik Gornji settlement (Table 1).

\begin{tabular}{lrrrrrrrr}
\hline & 1857 & 1869 & 1880 & 1890 & 1900 & 1910 & 1921 & 1931 \\
\hline Smoković & 376 & 377 & 472 & 483 & 570 & 641 & 738 & 867 \\
Zemunik Donji & 1,027 & 1,057 & 773 & 797 & 996 & 1,085 & 1,306 & 1,502 \\
Zemunik Gornji & 0 & 0 & 375 & 462 & 514 & 629 & 716 & 766 \\
Municipality & 1,403 & 1,434 & 1,620 & 1,742 & 2,080 & 2,355 & 2,760 & 3,135 \\
& & & & & & & & \\
& & 1948 & 1953 & 1961 & 1971 & 1981 & 1991 & 2001 \\
\cline { 2 - 7 } & & 1,012 & 1,113 & 1,166 & 1,107 & 1,015 & 1,029 & 50 \\
Smokovićn & & 1,951 & 2,240 & 2,472 & 2,230 & 2,003 & 2,318 & 1,466 \\
Zemunik Donji & & 1,077 & 1,296 & 1,322 & 1,198 & 1,249 & 1,310 & 387 \\
Zemunik Gornji & 4,040 & 4,649 & 4,960 & 4,535 & 4,267 & 4,657 & 1,903 \\
Municipality & & & & & & & &
\end{tabular}

Source: Settlements and population of the Republic of Croatia in the period 1857-2001, CD ROM, Croatian Central Bureau of Statistics, Zagreb, 2005

The reason for this population decline was the emigration of inhabitants of Serbian nationality during the Croatian War of Independence. In Smoković and Zemunik Gornji settlements, Serbs were the ethnic majority, while in Zemunik Donji the majority of inhabitants were Croats. Out of the total number of inhabitants living in the Municipality in 1991, 44.8\% were Croats, $44.7 \%$ were Serbs and $2.5 \%$ belonged to other nationalities. In 2001 all three settlements had only 1,903 inha- 
DRUŠ. ISTRAŽ. ZAGREB GOD. 20 (2011), BR. $4(114)$

STR. 1163-118

ŠILJKOVIĆ, ž. ČUKA, A., PEJDO, A. RURAL AREA... bitants, and there were $94.2 \%$ Croats, 3.3\% Serbs and 2.5\% others. During the Croatian War of Independence the frontline was placed between settlements with Serbian majority and those with Croatian majority, along which both parties laid explosive devices, including pressure-activated mines, with little regard to mapping or marking their exact location. After the War, the presence of landmines had a negative impact on the value of agricultural land, but also on the return of local inhabitants, because some of those devices were laid within the settlements in the vicinity of housing facilities and gardens within the settlements.

A significant decline of agricultural economic activities occurred during and after the Croatian War of Independence and can be observed by closely examining the population structure according to economic activity from 1971 to 2001. In 1971, $31 \%$ of the total economically active population living in the Municipality were engaged in agricultural activities. Based on information from the 1991 population census, the share of economically active agricultural population decreased to $12.8 \%$ which was still relatively high if compared to other rural settlements in the Zadar hinterland. This proves the thesis that until the beginning of the Croatian War of Independence, deagrarianisation was not such a prominent process in Zemunik Donji Municipality. After the War, in 2001, the share of the economically active agricultural population in the overall economically active population was only $1.74 \%$. In the Municipality, the total number of persons employed in the primary sector declined from 554 in 1971 to only 10 in 2001 . Along with the aforementioned economical restructuring from dominantly primary into secondary and tertiary activities, one of the main reasons for such a distinctively negative change was the Croatian War of Independence. Despite the intensive demining process, the problem of mined arable land will not completely enable agricultural valorisation of land as it was the case before the 1990s. Even in officially mine-free areas there have been accidents involving human casualties, so local inhabitants are sometimes suspicious and afraid to resume farming. An additional negative influence concerning the land use derives from the fact that after the War had ended a large share of inhabitants did not return to their homes, and due to their direct involvement in war activities some of them will probably never come back. Since most of the arable land is private property, it will stay uncultivated and in the near future this will result in regeneration of autochthonous vegetation.

In many developing countries civilian casualties occur mostly in rural areas as people go about their daily activities, often driven by economic necessity to go into areas known to be dangerous, as in Lebanon and Vietnam (ICBL, 2008). When refugees in the Republic of Croatia returned to their homes, they 
DRUŠ. ISTRAŽ. ZAGREB GOD. 20 (2011),

BR. 4 (114),

STR. 1163-1181

ŠILJKOVIĆ, Ž.,

ČUKA, A., PEJDO, A.:

RURAL AREA...

TABLE 2

Number of civilian casualties involved in UXO incidents, by counties and in Zemunik Donii Municipality in the period from 1991 to 2009

\section{TABLE 3}

Number of civilian casualties involved in UXO incidents, according to the economic activity they were performing at the moment of the accident in Zemunik Donji Municipality from 1991 to 2009 found their farms, pastures, forests and fields were mined. According to the CROMAC database, 756 civilians were involved in landmine and UXO incidents in the Republic of Croatia, in the period from 1991 to 2009, with as many as 273 killed. Most incidents were registered in Zadar, Sisak-Moslavina and Vukovar-Srijem County (more than one hundred casualties per county) (Table 2).

\begin{tabular}{lrrrr}
\hline County & $\begin{array}{r}\text { Minor } \\
\text { injuries }\end{array}$ & Killed & $\begin{array}{r}\text { Severe } \\
\text { injuries }\end{array}$ & Total \\
\hline Bjelovar-Bilogora & - & 2 & 4 & 6 \\
Slavonski Brod-Posavina & 2 & 3 & 8 & 13 \\
Dubrovnik-Neretva & - & 4 & 5 & 9 \\
Karlovac & 13 & 23 & 41 & 77 \\
Lika-Senj & 3 & 22 & 26 & 51 \\
Osijek-Baranja & 23 & 25 & 27 & 75 \\
Požega-Slavonia & 7 & 12 & 15 & 34 \\
Sisak-Moslavina & 27 & 34 & 61 & 122 \\
Split-Dalmatia & 7 & 17 & 9 & 33 \\
Sibenik-Knin & 3 & 13 & 42 & 58 \\
Virovitica-Podravina & 2 & 9 & 13 & 24 \\
Vukovar-Srijem & 16 & 41 & 48 & 105 \\
Zadar & 15 & 67 & 65 & 147 \\
Zagreb & - & 1 & 1 & 2 \\
Total & 118 & 273 & 365 & 756 \\
ZEMUNIK DONJI AREA & 2 & 10 & 10 & 22 \\
\hline
\end{tabular}

Source: CROMAC, 2009a

According to official statistics derived by CROMAC, civilians were injured or killed while collecting firewood, fishing or hunting, working in gardens, fighting fire, digging canals, cultivating land, grazing sheep or while performing some other agricultural work. In the period from 1991 to 2009, ten civilians were killed in the Zemunik area (Table 3).

\begin{tabular}{lrrrrr}
\hline Economic activity & $\begin{array}{r}\text { Number of } \\
\text { accidents }\end{array}$ & $\begin{array}{r}\text { Minor } \\
\text { injuries }\end{array}$ & $\begin{array}{r}\text { Severe } \\
\text { injuries }\end{array}$ & Killed & $\begin{array}{r}\text { Total } \\
\text { casualties }\end{array}$ \\
\hline Hunting/fishing & 1 & - & 1 & 1 & 2 \\
Unknown & 12 & 2 & 6 & 8 & 16 \\
Agriculture & 2 & - & 2 & - & 2 \\
Use of field roads & 1 & - & 1 & 1 & 2 \\
Total & 16 & 2 & 10 & 10 & 22 \\
\hline
\end{tabular}

Source: CROMAC, 2009b

Two accidents resulting in severe injuries were recorded in connection with agriculture, and one person was killed while using a field road. Landmines make fields unsafe for farming 
and represent a tremendous obstacle for the development of economic activities in predominately agricultural regions. In Zadar County 22\% of all incidents were related to agriculture.

\section{SOCIO-ECONOMIC CHANGES FROM THE FIRST HALF OF THE 19TH CENTURY TO THE PRESENT TIME}

Geographical descriptions, demographic and economic situation and land use data in the 19th century were analyzed based on the Economic description of cadastral municipality or Operato dell'Estimo censuario del Comune di Zemonico from 1844 (DAS, 1844). The document was made as a part of the so-called Second cadastral and geodetic survey completed by the Austrian Monarchy in the first half of the 19th century and it is preserved in the State Archives in Split. It is written in Italian and it includes data on topography, the geographical position of the Municipality, population number and their activities, cattle number and breed, and water sources. As a result of the field observations, the document contains relatively short descriptions of mentioned features. Its main purpose was to document agricultural land and to determine the annuity that needed to be paid. Similar documents can be found for most Dalmatian settlements. The analysis was undertaken within the boundaries of tax municipalities of that period. Those boundaries mostly correspond to current cadastral municipalities. The aforementioned document also included land survey and land use data from 1857 that can be compared with equivalent data from 2009. Based on this comparison of cadastral data and analyses of the arable land use change, the authors determined the prevalence of specific types of agriculture, both from 150 years ago and today.

According to the data from the Economic description, there were 799 inhabitants in 128 families and 158 households in the Zemunik area during the mid-19th century. That was a period of strong development in agriculture and demographic growth. The document also recorded the religious composition of the local population; there were 200 inhabitants of Orthodox and 598 of Catholic denomination and one priest, of unspecified religion. The document also reported that all the inhabitants of the region, the priest excluded, were involved in agricultural economy, which is not the case today. In 1857, $62.8 \%$ of the total population were economically active. By comparison, according to the Population Census 2001, this percentage dropped to just $39.41 \%$ with only $1.74 \%$ involved in active agriculture. The history of the settlements reveals an identical pattern to other Mediterranean open land landscapes where inhabitants constantly used the land up to the limits of its so-called "sustainable use" (Meeus et al., 1990). 
DRUŠ. ISTRAŽ. ZAGREB GOD. 20 (2011), BR. 4 (114),

STR. 1163-1181

ŠILJKOVIĆ, Ž., ČUKA, A., PEJDO, A.: RURAL AREA. TABLE 4
Cattle number in the
Zemunik area in 1844 and 2003
In the mid-19th century the total number of cattle shows that livestock farming, especially that of small stock (Table 4), dominated in the Zemunik area. Pastures covered almost $60 \%$ of the total area in the Municipality and $31 \%$ were plough-fields. In addition to cattle breeding, agriculture was also developed, and the most important products were various grain species and animal feedstuffs. Although the document recorded a relatively high number of large stock, those were mainly oxen used for ploughing, while small stock were important both for providing food and, to a lesser extent, to generate income.

\begin{tabular}{lrr}
\hline Cattle breed & 1844 & 2003 \\
\hline Bovine & 765 & 38 \\
Horses & 154 & 8 \\
Poultry & 13 & 9,515 \\
Donkeys and mules & 47 & 0 \\
Male-goats and goats & 2,171 & 93 \\
Sheep and lambs & 6,469 & 1,479 \\
Pigs & 89 & 135 \\
Total & 9,708 & 11,268 \\
\hline
\end{tabular}

Source: Operato dell'Estimo censuario del Comune di Zemonico, Economic description from 1844, State Archive in Split, Split, 2008; Agricultural Census 2003, Livestock, Poultry and other Animals, Croatian Central Bureau of Statistics, Zagreb, 2008

Statistical data from the 2003 Agricultural Census indicate the reduction of all kinds of animal husbandry, except poultry. Although the War had a significant influence on the Zemunik area, which is still partially devastated in terms of demographics and infrastructure, the reduction of cattle numbers relates to socio-geographic changes, intensified in the second half of the 20th century. Intensive processes of migration to the coastal area and industrialization caused a strong urban development of Zadar in the period after the 1960s had the largest influence on the Zemunik area and Zadar hinterland. The need for a labour force in the Zadar industry forced intensive ruralurban migrations (Pejdo \& Čuka, 2009). On the other hand, intensive commuting was noted from rural settlements with good traffic connections, situated closer to Zadar. Those settlements recorded significant changes in employment by economic sectors. Therefore, in 1971, in all three analyzed settlements, $22.5 \%$ of economically active population was employed in industry, while $31 \%$ was employed in agriculture. As there were no significant industrial plants in the Municipality at that time, one may conclude that all those employed in industry were daily commuters (Pejdo \& Čuka, 2009). In that period, the process of permanent emigration is far more intensified in 
DRUŠ. ISTRAŽ. ZAGREB GOD. 20 (2011), BR. 4 (114)

STR. 1163-118

ŠILJKOVIĆ, ž. ČUKA, A., PEJDO, A. RURAL AREA... the settlements remote from the coast. This proves that the geographical position had a crucial role in the population development of the Zemunik area (Čuka \& Pejdo, 2009). Due to a favourable geographic position, the processes of depopulation and deagrarianisation in the Zemunik area did not evolve considerably until the beginning of the Croatian War of Independence.

In the Zemunik area, a more significant population decrease was recorded after 1961 as the result of emigration, but agriculture remained the most important economic activity until 1991. While a significant portion of the population emigrated from Croatia, mostly to the Western European countries, the remainder stayed in the Zemunik area and worked in Zadar. After coming home from work most of the inhabitants worked in the fields. Since it was difficult for local inhabitants to combine permanent employment in industry as primary source of income, with cattle breeding as secondary source of income, they gradually abandoned the latter activity (except poultry keeping).

In the middle of the 19th century there were almost no olive trees in the Zemunik region and only $2 \%$ of the total arable land was given over to vineyards. Therefore, the only products that were exported to Zadar market were hay and firewood. Other agricultural products were sufficient solely to satisfy the requirements of local inhabitants. The quality of the local products was identical to that of neighbouring $\mathrm{Mu}$ nicipalities, and it is interesting that the local population produced only red wine grapes used for making medium quality red wine. All possible surpluses were sold in the Zadar market and it was also the place where inhabitants from the Zemunik area bought everything they did not produce or did not have in sufficient quantities. During the 20th century, vineyards became the most significant branch of fruit-growing, expanding from 68.9 ha to $165.8 \mathrm{ha}$, in the period from 1857 to 2009 .

\section{LAND USE CHANGES}

Land use changes of the Zemunik area were analyzed by the comparison of archival data from the mid-19th century with data from 1900 and current cadastral data. While analyzing the categorization of land use, it is necessary to point out that there are differences in categorizing pastures and forests between the archival data from 1857, Census data from 1900 and cadastral data from 2009. In 1857, in the Cadastral Municipality Zemunik, sections of the pastures with sparse underbrush vegetation were within the category named forested pastures, whereas in the new categorization, that same category does not exist. In addition, non-arable land, roads, yards, paths and waters were not differentiated in 1857 . In order to simplify the a- 
DRUŠ. ISTRAŽ. ZAGREB GOD. 20 (2011)

BR. 4 (114),

STR. 1163-1181

ŠILJKOVIĆ, Ž.,

ČUKA, A., PEJDO, A.: RURAL AREA.

(1) TABLE 5

Comparison of land use change in Cadastral Municipality

Zemunik in 1857,

1900 and 2009 nalysis, the aforementioned categories were presented collectively for years 1900 and 2009. In all analysed years the above mentioned categories were referred to as 'other' and 'non-arable land'. Although the data for 2009 were obtained from the State Geodetic Administration of the Republic of Croatia (branch-office Zadar), they do not represent the actual situation, which was clearly noted on the field and then confirmed by detailed analyses of the mine suspected areas. Considering relatively minor changes in land use throughout the last 150 years, it is evident that the events of the recent war activities which had a directly negative influence on the agrarian use of the Cadastral Municipality Zemunik were not recorded in the cadastral records, i.e. records from 2009 reflect the situation before the Croatian War of Independence.

Depopulation and deagrarianisation processes in the second half of the 20th century, especially evident in the rural settlements in the hinterland, did not have a strong influence on the analyzed region until the Croatian War of Independence. Land use analysis clearly indicates development of agriculture which consequently caused the increase of land under plough-fields, vineyards and orchards and the overall decrease of pastures. One of the facts that should not be omitted is that Zadar Airport and military airbase are located within the borders of Zemunik Donji Municipality, significantly influencing the increase of land categorized as buildings, other or non-arable (Table 5).

\begin{tabular}{|c|c|c|c|c|c|c|}
\hline \multirow[b]{2}{*}{ Land use } & \multicolumn{2}{|r|}{1857} & \multicolumn{2}{|r|}{1900} & \multicolumn{2}{|r|}{2009} \\
\hline & ha & $\%$ & ha & $\%$ & ha & $\%$ \\
\hline Plough-fields & $1,166.9$ & 31.0 & $1,189.0$ & 31.6 & $1,369.9$ & 36.4 \\
\hline Vineyards & 69.0 & 1.9 & 156.0 & 4.1 & 165.8 & 4.4 \\
\hline Orchards & 8.7 & 0.2 & 20.0 & 0.5 & 20.7 & 0.6 \\
\hline Meadows & 106.4 & 2.8 & 106.0 & 2.8 & 203.3 & 5.4 \\
\hline Pastures & $1,007.3$ & 26.7 & $1,326.0$ & 35.2 & 650.2 & 17.3 \\
\hline Wooded pastures & $1,242.5$ & 33.0 & - & - & - & - \\
\hline Forests & 121.7 & 3.2 & 899.0 & 23.9 & 825.3 & 21.9 \\
\hline Buildings & 7.4 & 0.2 & - & - & 382.5 & 10.2 \\
\hline Other and unarable & 37.9 & 1.0 & 70.0 & 1.9 & 149.6 & 4.0 \\
\hline Total & $3,766.9$ & 100.0 & $3,766.0$ & 100.0 & $3,766.9$ & 100.0 \\
\hline
\end{tabular}

Source: Operato dell'Estimo censuario del Comune di Zemonico, Economic description from 1844, State Archive in Split, Split, 2008; Općinski rječnik za kraljevine i zemlje zastupane u Carevinskom vijeću, XIV.: Dalmacija, C. Kr. središnja statistička komisija, Beč, 1908; State Geodetic Administration of the Republic of Croatia, branch-office Zadar, Zadar, 2009

The increase of arable land and the significant decrease of pastures indicate development of crop-farming and reduction of cattle breeding. The reduction of cattle breeding can be attributed to the increase in the number of inhabitants em- 
DRUŠ. ISTRAŽ. ZAGREB GOD. 20 (2011), BR. 4 (114),

STR. 1163-1181

ŠILJKOVIĆ, Ž. ČUKA, A., PEJDO, A. RURAL AREA...
2 TABLE 6

Current land use categories for $18.7 \%$ of the total mine suspected area in Zemunik Donii Municipality, according to official cadastral data ployed at Zadar Airport which is located in the Municipality, Zemunik military base, in the Zadar industry and other services. For most of them agriculture has become a secondary source of income. Such circumstances enabled the inhabitants of Zemunik Donji to enjoy significant economic growth in the period before the Croatian War of Independence. The Croatian War of Independence, and the subsequent period, suspended the economic growth of the entire region. Bombardments destroyed the largest portion of housing and economic facilities and even though the infrastructure has been partially rebuilt, landmines still remain the prime issue.

After the War 1,163 ha of land or $31 \%$ of the Municipality area was a mine suspected area. According to the latest data from the Croatian Mine Action Centre (branch-office Zadar), 612 ha or almost $17 \%$ of the Zemunik Donji Municipality is still a mine suspected area. Large portions of that land are arable plough-fields and crofts.

In order to prove the fact that cadastral data are not updated, detailed analyses was done. From the maps of mine suspected areas overlapped with cadastral maps containing cadastral parcels, provided by CROMAC branch-office in Zadar, the authors singled out all the cadastral parcels marked as mine suspected. Some of the parcels are only partially mined and those were not considered for analyses. For this kind of land use analyses the authors picked out only the ones that had the total area categorized as mine suspected. Out of 612 ha of the currently mine suspected area, 114.6 ha or $18.7 \%$ was analysed. Current land use category and superficies of 244 cadastral parcels were determined according to data available on the official web site of the Croatian Ministry of Justice. The final results showed that almost $36 \%$ of the investigated area is still categorized as arable land, mostly covered by plough-fields (Table 6).

\begin{tabular}{lrr}
\hline Land use categories & Area in ha & $\%$ in total \\
\hline Plough-fields & 36,0 & 31.4 \\
Vineyards & 4,8 & 4.2 \\
Orchards & 0,3 & 0.2 \\
Total arable & 41,1 & 35.9 \\
Meadows & 4,5 & 3.9 \\
Pastures & 12,2 & 10.7 \\
Forests & 56,4 & 49.2 \\
Total non-arable & 73,1 & 63.8 \\
Non fertile & 0,4 & 0.4 \\
Total & 114,6 & 100.0 \\
\hline
\end{tabular}

Source: Made after maps provided by CROMAC branch-office in Zadar and Cadastral Data from http://www.pravosudje.hr 
Since there was no agricultural activity in the mine suspected area for almost 20 years, arable land was abandoned and the succession of natural vegetation resulted in degradation of the traditional agricultural landscape.

\section{CONCLUSION}

From the beginning of the 19th to the beginning of the 21st century the agricultural landscape of the Zemunik Donji Municipality evolved from pastures and cropland to mine fields, being a case example for similar rural regions in the Republic of Croatia. In accordance with favourable natural-geographic and socio-economic conditions, the population mostly increased in the period between 1857 and 1991. As a consequence of the Croatian War of Independence and economic issues, the total population decreased by 59.1\% between 1991 and 2001. Agriculture is the economic activity that was most adversely affected by the War. In 2001 merely 1.74\% of the economically active population was engaged in agriculture.

Minefields and other areas suspected of being contaminated with mines and unexploded ordnance were located in 12 of 21 counties in Croatia. In 2009 the mine suspected area was $954.5 \mathrm{sq} . \mathrm{km}$. Within the territory of the Republic of Croatia, landmine fields are most widespread in those parts of the country where the line of separation between two warring parties was located during the Croatian War of Independence. The line of separation was in the arable area of Ravni kotari, as it was inhabited by both Croats and Serbs before the war, and this resulted in laying of numerous landmine fields. From 1995 to 2009 the mine suspected area within the Zemunik Donji Municipality was reduced from $31 \%$ to $17 \%$.

Solving landmine issues is a prerequisite for spatial management and hence also economic and social development (Biljecki et al., 2006). Fear of the presence of even a single landmine can deny people access to land that they desperately need for agriculture, water supply or to undertake conservation measures (Berhe, 2007). This is a key reason why almost 15 years after the war the inhabitants of traditionally agricultural regions in Croatia have still not reengaged in the same activities as they were before the 1990s.

Andersson, N., Swaminathan, A., Whitaker, C. and Roche, M. (2003), Mine Smartness and the Community Voice in Mine-Risk Education: Lessons from Afghanistan and Angola. Third World Quarterly, 24 (5): 873-887. doi:10.1080/0143659032000132902

Antonić, D., Ban, Z. and Žagar, M. (2001), Demining Robots, Requirements and Constraints. Automatika, 42 (3-4): 189-197.

Berhe, A. A. (2007), The Contribution of Landmines to Land Degradation. Land Degradation \& Development, 18 (1): 1-15. doi:10.1002/ldr.754 
DRUŠ. ISTRAŽ. ZAGREB GOD. 20 (2011), BR. $4(114)$ STR. 1163-1181

ŠILJKOVIĆ, Ž. ČUKA, A., PEJDO, A.: RURAL AREA...
Biljecki, Z., Pavičić, S. and Tonković, T. (2006), Concept and Establishment of the Mine Information System within the CROMAC GIP Project. Cartography and Geoinformation, 5 (6): 76-88.

Bürgi, M., Hersperger, A. M. and Schneeberger, N. (2004), Driving Forces of Landscape Change - Current and New Directions. Landscape Ecology, 19 (8): 857-868. doi:10.1007/s10980-004-0245-8

Croatian Mine Action Centre - CROMAC (2006), Standard Operating Procedures, Mine Suspected Area Survey, Technical Survey Using Mechanical Demining Method and Humanitarian Demining. In Croatian: Postupci prilikom razminiranja, pregled minski sumnjivih područja, protuminsko djelovanje koristeći mehaničke metode razminiranja i humanitarno razminiranje, Hrvatski centar za razminiranje, Oto Jungwirth, Zagreb.

Croatian Mine Action Centre - CROMAC (2009a), Data on Civilian Casualties by Counties and in Zemunik Donji Municipality in the Period from 1991 to 2009 and Data on Mine Suspected Area in 2009. In Croatian: Podaci o civilnim žrtvama po županijama i za općinu Zemunik Donji u razdoblju od 1991. do 2009. i podaci o minski sumnjivim područjima u 2009., Hrvatski centar za razminiranje, Sisak.

Croatian Mine Action Centre - CROMAC (2009b), Number of Civilian Casualties According to the Economic Activity They Were Performing at the Moment of the Accident in Zemunik Donji Municipality from 1991 to 2009. In Croatian: Broj civilnih žrtava s obzirom na ekonomsku aktivnost koju su obavljali u trenutku nesreće, u općini Zemunik Donji, u razdoblju od 1991. do 2009. godine, Hrvatski centar za razminiranje, Sisak.

Croatian Ministry of Justice (2010), Current Land Use Categorization of 244 Parcels in Zemunik Donji Municipality. In Croatian: Trenutna kategorizacija 244 zemljišne čestice na prostoru Općine Zemunik Donji, http:// www.pravosudje.hr (10. 6. 2010)

Čuka, A. and Pejdo, A. (2009), Društveno geografska preobrazba ruralnog krajolika Ravnih kotara u 2. polovini 20. stoljeća. In: T. Oršolić (Ed.), Zadar i okolica od Drugoga svjetskog rata do Domovinskog rata (pp. 444-465), Matica Hrvatska, Zavod za povijesne znanosti HAZU, University of Zadar, Zadar.

Day, W. (1998), Removing Landmines - One Limb at a Time? Journal of Public Health Policy, 19 (3): 261-266. doi:10.2307/3343535

Elliot, G. and Harris, G. (2001), A Cost Benefit Analysis of Landmine Clearance in Mozambique. Development Southern Africa, 18 (5): 625-633. doi:10.1080/03768350120097469

Geneva International Centre for Humanitarian Demining - GICHD (2004), A Guide to Socio-Economic Approaches to Mine Action Planning and Management, Geneva.

Gibson, J., Barns, S., Cameron, M., Lim, S., Scrimgeour, F. and Tressler, J. (2007), The Value of Statistical Life and the Economics of Landmine Clearance in Developing Countries. World Development, 35 (3): 512-531. doi:10.1016/j.worlddev.2006.05.003

Gilland, B. (2006), Population, Nutrition and Agriculture. Population and Environment, 28 (1): 1-16.

Goldewijk, K. K. and Ramankutty, N. (2004), Land Cover Change over the Last Three Centuries Due to Human Activities: The Availability of New Global Data Sets. GeoJournal, 61 (4): 335-344. 
DRUŠ. ISTRAŽ. ZAGREB GOD. 20 (2011), BR. 4 (114),

STR. 1163-1181

ŠILJKOVIĆ, Ž., ČUKA, A., PEJDO, A.: RURAL AREA.
Harpviken, K. B., Millard, A. S., Kjellman, K. E. and Skåra, B. A. (2003), Measures for Mines: Approaches to Impact Assessment in Humanitarian Mine Action. Third World Quarterly, 24 (5): 889-908. doi:10. 1080/0143659032000132911

Harpviken, K. B. and Skåra, B. A. (2003), Humanitarian Mine Action and Peace Building: Exploring the Relationship. Third World Quarterly, 24 (5): 809-822. doi:10.1080/0143659032000132867

Harris, G. (2000), The Economics of Landmine Clearance: Case Study of Cambodia. Journal of International Development, 12 (2): 219-225. doi:10. 1002/(SICI)1099-1328(200003)12:2<219::AID-JID638>3.3.CO;2-D

Harris, G. (2002), The Economics of Landmine Clearance in Afghanistan. Disasters, 26 (1): 49-54. doi:10.1111/1467-7717.00190

Harte, J. (2007), Human Population as a Dynamic Factor in Environmental Degradation. Population and Environment, 28 (4-5): 223-236. doi:10.1007/s11111-007-0048-3

Horwood, C. (2003), Ideological and Analytical Foundations of Mine Action: Human Rights and Community Impact. Third World Quarterly, 24 (5): 939-954. doi:10.1080/0143659032000132948

Institute for Physical Planning (2006.), Physical Plan of Zemunik Donji Municipality. In Croatian: Prostorni plan uređenja općine Zemunik Donji, Zavod za prostorno planiranje, Zadarska županija, Zadar.

International Campaign to Ban Landmines - ICBL (2006), International Campaign to Ban Landmines Report of Activities. Landmine Monitor. Mines Action Canada, Canada.

International Campaign to Ban Landmines - ICBL (2008), Toward a Mine-Free World. Executive Summary. Landmine Monitor. Mines Action Canada, Canada

Kizos, T. and Koulouri, M. (2006), Agricultural Landscape Dynamics in the Mediterranean: Lesvos (Greece) Case Study Using Evidence from the Last Three Centuries. Environmental Science \& Policy, 9 (4): 330-342. doi:10.1016/j.envsci.2006.02.002

Kjellman, K. E., Harpviken, K. B., Millard, A. S. and Strand, A. (2003), Acting as One? Co-Ordinating Responses to the Landmine Problem. Third World Quarterly, 24 (5): 855-871. doi:10.1080/0143659032000132894 Lasanta-Martínez, T., Vicente-Serrano, S. M. and Cuadrat-Prats, J. M. (2005), Mountain Mediterranean Landscape Evolution Caused by the Abandonment of Traditional Primary Activities: A Study of the Spain Central Pyrenees. Applied Geography, 25 (1): 47-65. doi:10.1016/j.apgeog. 2004.11.001

Mahmudi-Azer, S. (2006), Arms Trade and its Impact on Global Health. Theoretical Medicine and Bioethics, 27 (1): 81-93. doi:10.1007/s11017-005$5753-2$

Marandola Jr., E. and Hogan, D. J. (2006), Vulnerabilities and Risks in Population and Environment Studies. Population and Environment, 28 (2): 83-112.

Meeus, J. H. A., Wijermans, M. P. and Vroom, M. J. (1990), Agricultural Landscapes in Europe and their Transformation. Landscape and Urban Planning, 18 (3-4): 289-352. doi:10.1016/0169-2046(90)90016-U 
DRUŠ. ISTRAŽ. ZAGREB GOD. 20 (2011), BR. 4 (114) STR. 1163-1181

ŠILJKOVIĆ, Ž. ČUKA, A., PEJDO, A. RURAL AREA...
Mitchell, S. K. (2004), Death, Disability, Displaced Persons and Development: The Case of Landmines in Bosnia and Herzegovina. World Development, 32 (12): 2105-2120. doi:10.1016/j.worlddev.2004.08.004

Općinski rječnik za kraljevine $i$ zemlje zastupane u Carevinskom vijeću, XIV.: Dalmacija, C. Kr. središnja statistička komisija, Beč, 1908.

Pebley, A. R. (1998), Demography and the Environment. Demography, 35 (4): 377-389. doi:10.2307/3004008

Pejdo, A. and Čuka, A. (2009), Utjecaj Maraske na suvremenu društveno-geografsku preobrazbu zadarskog kraja. In: A. Bralić and J. Faričić (Ed.), Višnja maraska i proizvodi od nje - bogatstvo Zadra i zadarske regije, University of Zadar, Maraska d.d., Zadar, in press, Zadar.

Petanidou, T., Kizos, T. and Soulakellis, N. (2008), Socioeconomic Dimensions of Changes in the Agricultural Landscape of the Mediterranean Basin: A Case Study of the Abandonment of Cultivation Terraces on Nisyros Island, Greece. Environmental Management, 41 (2): 250-266. doi:10.1007/s00267-007-9054-6

Potts, M. (2007) Population and Environment in the Twenty-First Century. Population and Environment, 28 (4-5): 204-211. doi:10.1007/s11111007-0045-6

Radonić, V., Giunio, L., Vidjak, V., Boschi, V., Barić, D. and Stipić, R. (2004), Mine Clearance Injuries in South Croatia. Military Medicine, 169 (8): 642-647.

Rain, D., Long, J. and Ratcliffe, M. (2007), Measuring Population Pressure on the Landscape: Comparative GIS Studies in China, India and the United States. Population and Environment, 28 (6): 321-336. doi:10.1007/s11111-007-0055-4

Roura-Pascual, N., Pons, P., Etienne, M. and Lambert, B. (2005), Transformation of a Rural Landscape in the Eastern Pyrenees between 1953 and 2000. Mountain Research and Development, 25 (3): 252-261. doi:10.1659/0276-4741(2005)025[0252:TOARLI]2.0.CO;2

Ruiz Perez, M. (1990), Development of Mediterranean Agriculture: An Ecological Approach. Landscape and Urban Planning, 18 (3-4): 211-219. doi:10.1016/0169-2046(90)90007-O

State Archive in Split - DAS (1844), Operato dell'Estimo censuario del Comune di Demonico. In Croatian: Ekonomski opis iz 1844., Državni arhiv u Splitu, Split.

State Geodetic Administration of the Republic of Croatia, Branch-Office Zadar (2009), Land Use Data on Zemunik Cadastral District. In Croatian: Podaci o korištenju zemljišta u katastarskoj općini Zemunik Donji, Državna geodetska uprava, područni ured za katastar Zadar, Zadar.

Zomeni, M., Tzanopoulos, J. and Pantis, J. D. (2008), Historical Analyses of Landscape Change Using Remote Sensing Techniques: An Explanatory Tool for Agricultural Transformation in Greek Rural Areas. Landscape and Urban Planning, 86 (1): 38-46. doi:10.1016/j.land urbplan.2007.12.006 
DRUŠ. ISTRAŽ. ZAGREB GOD. 20 (2011) BR. 4 (114),

STR. 1163-1181

ŠILJKOVIĆ, Ž.,

ČUKA, A., PEJDO, A.: RURAL AREA..
Preobrazba ruralnih prostora: od oranica do minskih polja studija slučaja općine Zemunik Donji

Željka ŠILJKOVIĆ, Anica ČUKA, Ana PEJDO

Sveučilište u Zadru, Zadar

U članku su analizirane društveno-gospodarske promjene i promjene iskorištavanja zemliišta općine Zemunik Donji u 19. i 20. st. Dan je i pregled minski sumnivih područja i civilnih žrtava u regiji te utjecaj miniranosti na kretanje broja stanovnika. Općina Zemunik Donji dio je Ravnih kotara, jedne od najvažnijih poljoprivrednih regija primorske Hrvatske. Tijekom povijesti, liudi koji su obitavali na ovim prostorima najvećim su se dijelom bavili poljoprivredom (podjednako poljodjelstvom i stočarstvom), koja im je omogućila opstanak i gospodarski razvoj. Usprkos intenzivnim procesima depopulacije i deagrarizacije, koji su u drugoi polovici 20. stoljeća zahvatili i ovai prostor i ostale dijelove primorske Hrvatske, krajolik općine Zemunik Donji zadržao je obilježja poljoprivredne regije. Kao posljedica Domovinskoga rata, u općini su se dogodile osjetne promjene, koje su rezultat zapuštanja poljoprivredne dielatnosti, a nekoć plodna polja danas su još uvijek dijelom minski sumniiva.

Ključne riječi: općina Zemunik Donji, upotreba zemliišta, minska polja

Der rurale Raum im Wandel:

Vom Landbaugebiet zum Minenfeld Eine Fallstudie zur Lage in der Gemeinde Zemunik Donji

Željka ŠILJKOVIĆ, Anica ČUKA, Ana PEJDO Universität Zadar, Zadar

Der vorliegende Artikel widmet sich der Analyse des gesellschafflich-wirtschaftlichen Wandels sowie der Veränderungen im Landbau, die sich im Laufe des 19. und 20. Jahrhunderts auf dem Gemeindegebiet von Zemunik Donji..(bei Zadar) vollzogen. Des Weiteren erhält der Leser eine Übersicht von Minensperrgebieten, Opferzahlen unter der Zivilbevölkerung und demografischen Angaben. Die Gemeinde Zemunik Donji gehört zu Ravni Kotari, einer der bedeutendsten landwirtschaftlichen Regionen des kroatischen Küstenbereichs. In der Vergangenheit betrieb man hier zumeist Landwirtschaft (Ackerbau und Viehzucht zu gleichen Teilen), was der Bevölkerung Fortbestand und wirtschaftlichen 
DRUŠ. ISTRAŽ. ZAGREB GOD. 20 (2011), BR. 4 (114)

STR. 1163-1181

ŠILJKOVIĆ, Ž

ČUKA, A., PEJDO, A.:

RURAL AREA.
Aufschwung sicherte. Trotz intensiver Abwanderung und Deagrarisierung, die in der zweiten Hälfte des 20.

Jahrhunderts nicht nur diesen Raum, sondern auch die übrigen Teile des kroatischen Küstenbereichs erfassten, konnte sich Zemunik Donji die Merkmale einer landwirtschaftlichen Region bewahren. Allerdings kam es infolge des Kriegsgeschehens 1991-95 zu massiven Veränderungen mit dem Ergebnis, dass weite Teile der einstigen Landflächen vernachlässigt wurden und als Minensperrgebiete brachliegen.

Schlüsselbegriffe: Gemeinde Zemunik Donji, Landnutzung, Minensperrgebiete 